\title{
MAKE A MATCH AS TEACHING TECHNIQUE TO IMPROVE STUDENTS' WRITING
}

\author{
Anggia Nirma Saresti \\ STKIP PGRI Jombang \\ nirma_anggia@yahoo.com \\ Rosi Anjarwati \\ STKIP PGRI Jombang \\ rosi.stkipjb@gmail.com \\ Universitas Pesantren Tinggi Darul Ulum
}

\begin{abstract}
Teaching writing to junior high school students is absolutely a challenging job for English teacher in Indonesia, it also happened in a junior high school in Jombang. The researchers found that both teacher and students got problem in writing process because of the students' low ability in writing and monotonous writing teaching technique used by the teacher. This research used a Classroom Action Research design to solve the problem by using Make a match teaching technique. Make a match is considered to be one of cooperative learning method which has some benefits in teaching learning process. The result of data analysis indicates that Make a match bring benefits to improve students' writing and class participation.
\end{abstract}

Keywords: make a match, writing

\section{A. INTRODUCTION}

Writing is productive skill which starts from the process until get the result of writing. In writing for study the teacher asks the students to do the process of writing as well in order to get the best product of writing. In other way writing is arranging words to be good sentences based on the rules. Making good sentences based on the rules is the basic term to study writing. When the students are able to make good sentences, it will be easy for teacher to teach the process of writing. Process of writing consists of several steps, they are finding a topic, outlining, drafting, revising and editing, writing final product (Fachrurrazy, 2012). Moreover, Harmer (2008) states that writing is helpful to make a distinction between writing-for-learning and writing-for- writing. In this case of the former, writing is used as an aide- mémoire or practice tool to help students practice and work with language they have been studying.

Writing is one of the important parts in teaching learning proccess. It is important for students to be able to make good writing in teaching learning proccess. In fact, many students are dificult to make good writing. The reseacher join in VII F of SMPN I Megaluh to know writing ability in that class, the result is many students are not interested in writing. Besides, the reseacher did interview with the teacher and gave questionnaire to the students. The teacher said that the students have low ability in writing. The result of the quesionaire showed that writing is important to students but the students are dificult to write. It is caused by the method of teaching learning proccess is not interesting.

The reseacher found writing problem in VII F class. So the reseacher wanted to give new strategy in teaching learning proccess especially in writing. 
Make a match is one of cooperative learning, it is done in group. Cooperative learning is group study. It means that the students study in a group. The students disscuss and solve the problem with their friends. Cooperative learning emphasize in grouping, how the students work in a group which consists of two or more students. In cooperative learning the students in group have different caracteristic and different ability. There are five elements of cooperative learning (Johnson, 1994) they are; the students need each other, responsible, personality interaction, disscussing ability, and grouping proccess.

Cooperative learning is developed to reach at least three purposes (Ibrahim, 2000). The first purpose is students' achievement. It means that by using cooperative learning the students' achievement should increase. The second purpose is receiving the differences between heir friends. it means that the students should receive their friends in a group, because the group is homogeneous. The third purposes is developing social skill. It means that the students should be able to do team work and colaboration.

By implementing interesting strategy the students will be motivated (Zaini, 2008). Make a match can be used for all subject and all lerners' level. Curran (1994) said that one of Make a match profits is the students look for their partner while learning a topic in interesting situation. Make a match can create interesting situation because, the students will not only sitting and listening the teacher, but they can do physical event and move around the class to look for their partner.

The role of make a match is the teacher prepares a number of paired cards. Each pair contains the same problem. Every students is given a card, and asked to find the partner. By using cooperative learning, it can make the students get new situation in teaching learning proccess. It can motivate the students to make good writing.

Make a match can motivate students to study. By using make a match students can be active in teaching learning proccess, because the students are not only silent and listen the teacher gives explanation but also the students can do physical activity to find the partner. The students can go around the class to find the partner. After finding the partner, the students should solve the problem that the students got from the teacher by doing discussion. Pratiwiningsih (2013) in her research explained that Make a match has some benefits, they are; it can increase student's learning activity for their cognitive and physic, it can increase students comprehension about the material, it can increase students motivation in learning, it can increase students score, and it can create fun learning because it is like a game. Based on the benefits above the reseacher conduct the research to teach writing procedure text, because Make a match is good way to teach the students who are not interested in teaching learning process especially in writing procedure.

The researcher chose Make a match as the strategy in teaching writing procedure because it can create joyfull learning (Pratiwiningsih, 2013). There are some previous studies related to the study, that is done by Chotimah (2013) In her research showed that the students who were taught by using make a match got higher score than the students who were not taught by using make a match students. The second previous study that is done by Sitepu (2014) showed that make a match effective to improve writing procedure text in eleventh grade of SMAN 1 Lau Baleng. In the research consist of two cycles, in the first cycle consist of three meetings and the second cycle consist of two meetings.

This research aimed at describing the improvement of VII F students' writing procedure text of SMPN 1 Megaluh through make a match teaching technique.

\section{B. METHOD}

\section{Research Design}

Research design in this study is Classroom Action Research (CAR) which is focused on students' problem in the class. It means that, before conducting this research, the researcher has found the problem in the class and then the researcher gives the solution to solve the problem by giving new 
teaching technique or using new media. Koshy (2005) argues that action research involves a spiral of self-reflective spirals of: 1) planning a change, 2) acting and observing the process and consequences of the change, 3) reflecting this processes and consequences and then re-planning, 4) acting and observing, 5) reflecting. From the explanation above, action research has some ways. Start from the researcher find out the problem until the researcher do reflecting to know the problem has solved or not.

Classroom Action Research is done in several cycles each of which is repeated in the following cycle if the result is not satisfactory yet with the better revised lesson plan. Each cycle begins with planning, implementing the plan, observing the implementing, and reflecting or evaluating the process and the result of the implementation. The result of the reflection determines the following cycle (Latief, 2013).

\section{Research Procedure}

\section{Preliminary Study}

In preliminary study, the researcher gave questionnaire to the students of VII F, did interview with the teacher, and observing the class. The result in preliminary study as follow:

a. From questionnaire, it was gotten that 75,86 $\%$ of students considered writing as important thing for them, but they felt difficult to write sentences. When the teacher explained the lesson most of students are not interested, because the teacher use usual method and the method is boring. It was shown by the result of the students' opinions, there are $79 \%$ students said that the method was boring. Because the method in teaching learning proccess is boring so the students felt dificult to understand the lesson.

b. In preliminary study, the researcher also did interview with the teacher. Tthe teacher said that the problem of seventh grade is complex. The students are not able to write in good way. Based on the interview the teacher said that the quality of the students is same as the previous class, there is no improvement. The teacher wants to improve the students' ability and the teacher also wants to motivate them to make good writing by using new teaching technique.

c. Besides giving questionnaire and doing interview the researcher also did observation in the class. The result in observing the class was many of students were talking with their friends when the teacher explained the lesson, in fact when the teacher gave task they could not do it well. It caused the teacher did not use interesting method. The teacher only explained the lesson use usual method, and the students onlyy sitting and listening the explanation from the teacher.

2. Planning

a. Teaching strategy

The researcher prepared teaching strategy before teaching in the class. Based on the result in preliminary study, the researcher choosed Make a match strategy to teach the class. In teaching learning proccess by using Make a match, the researcher prepare different cards, which on the first cards there is uncomplete steps of procedure text and the other cards is the answer of the first cards. Make a match strategy can create students' motivation because the students will do physical event in the class, so the students will not only sitting and listening teacher's explanation.

b. Lesson Plan

Before conducting the research the researcher make a lesson plan. In lesson plan, the researcher hopes that the students can complete procedure text, can make procedure text, and can write procedure text correctly. In teaching learning process, the teacher gives vocabularies related with procedure text, then explain about procedure text and the component of procedure text using make a match method. After that the students are asked to demonstrate making procedure text in front of the class by using a simple thing like a paper, glue, and cutter. The last is the students are asked to make the steps of procedure text in a group and the teacher reflects it.

\section{c. The Criteria of Success}

The criteria of success was set up to determine whether the action in the research was successfully completed or not. In line with this study, the criteria 
of success for students' writing score is $\geqslant 75 \%$ of the students with individual score in writing procedure text achieve at least the same as or above 70. It is established on the basis of the scores of the students' writing analyzed by analytic scoring rubrics. Besides, the second criteria of success is students participation should achieve $\geqslant 50 \%$.

\section{Implementing}

The implementation of the action was focused on what has been proposed in the lesson plan. The researcher acted as a practitioner who carried out the make a match technique in teaching writing. The implementation of the action covered two meetings each cycle. The steps of the implementation of this strategy in every cycle were described as follows: First is pre-activity. In this activity the researcher gave opening and explaining the lesson to the students. The students should understand and know what activity that they will do during learning process.Second, main activity in the first meeting. In this activity the researcher explained the lesson. The researcher explained more about procedure text and also give more vocabularies which are related to procedure text. After explaining more about procedure text the researcher asked the students to make a simple procedure text. Before it the researcher gave some questions to students about Present Tense to know the ability of students about Present Tense. Third, in post-activity activity the researcher reflected the activities that have been done. Besides that the researcher asked the students to learn more about procedure text and vocabulary related to procedure text.

\section{4. $\quad$ Observing}

Observing is the process of recording and gathering all relevant data about any aspect occurred during the implementation of the action. The researcher involved herself in the teaching and learning process in the class, during the teaching and learning process of writing using make a match technique. In observing part the researcher needs instrument to collect the data. Besides the instrument to collect the data the researcher give validity and reability. The instrument in this research as follow: a. Instrument and data collection method

1) Questionnaire

The researcher used questionnaire to get the information from the students about writing. The researcher asked the students to answer some questions about writing. The researcher knew the students opinion about writing. The form of questionnaire is multiple choice. There are ten questions in questionnaire. The indicators of questionnaire are student's opinion about writing, students' opinion about the way of teaching learning process, student's opinion about student's activity in the class, and student's opinion about the technique which is used teacher to teach in the class.

\section{2) Test}

After the researcher knew the problem of the students, the researcher made a strategy how to teach the students to solve the problem. After teaching, the researcher gave the student test to know the strategy can solve the problem or not. There is only a question in the test. The kind of test is essay, and the indicators of the test are the students can identify procedure text, make procedure text, and write procedure text correctly. For the test, the researcher did try out to other students in order to know the test valid or not. Besides, this research uses inter-rater to know the reliability of the test. This research uses 5 raters to get the score for one sample of students which the score would be calculated. The researcher analyzed the scoring rubric which consists of organization, language, content, vocabulary, and mechanics.

\section{3) Field note}

The researcher used field note to know how the process of implementing make a match strategy in the class. The teacher records during the implementation make a match strategy. By using field note, the researcher will know what are the advantages and the weakness of implementing make a match strategy. Besides, the researcher used field note to revise the previous cycle when the next cycle is needed.

b. Instrument validity and reliability

Validity is the extent to which references made from assessment result appropriate, meaningful, and 
useful in terms of purpose of the assessment. So an instrument is called to be valid if it measures what should be measured (Brown, 2004). It means that before the researcher gave test to the students the content of the test sould be valid. There are three aspects of validity, they are construct valididy, content validity and criterion validity. Construct validity is measuring what can be measured. It means the test is believed to be able to allow the students to show the writing to be assesed. And content of validity is related with scoring rubric. The assesment of writing test contain several aspects of writing, they are organization, language, content, vocabulary, and mechanics (Latief, 2013). Criterion validity is measured by SPSS 16. To measure the test is valid or not, the researcher used SPSS 16. Ary (2006) said that reliability is concerned with the effect of error on the consistency of score. It means that the score for the sould be consistent. In this case, the researcher used 5 rater to give score for the sample of the test.

\section{Reflecting}

Reflecting is proposed to see the success or the failure of what has been done in previous action or during the action. In reflecting, the researcher and the teacher discussed together the implementation and observation during the teaching and learning process in the classroom. If the collected data in the first cycle revealed that the criteria of success have been fulfilled, there would be no more cycle to conduct. On the contrary, if the conclusions proved the criteria of success have not been fulfilled, it needs to move to the next cycle concerning replanning, re-acting, and re-observing.

\section{FINDINGS AND DISCUSSION}

\section{Findings}

Findings discussed the data that were collected during implementing Make a match strategy. The data collected were related to the criteria of success. The criteria of success were students' achievement in writing procedure text based on the test and students participation based on the questionnaire. The following parts describe finding in cycle 1 and cycle 2.
1. Cycle 1

a. Students' achievement

Students' achievement was gained from test. There is a question in the test and the test is essay. In doing a test the researcher had determined the criteria of success that is $\geqslant 75 \%$ students got score 70 upper. If the criteria of success have reached by the students the research is done well, but if the students cannot reach the criteria of success, the researcher should revise the first cycle and continue to the next cycle. From the test that was given to the students there were 12 students reached criteria of success, and 17 students got score under criteria of success. The result in cycle 1 was $41,38 \%$ students had reached criteria of success and $58,62 \%$ students did not reach criteria of success.

b. Students' participation

The result of questionnaire that related with students participation are: (1) question number 3 showed that $69 \%$ of students through make match, the students were motivated to study English when they solve the problem in a group. (2) question number 5 showed that $69 \%$ of students said that group presentation in make a match made students more active in asking question. (3) question number 6 showed that $59 \%$ of students said that group presentation in make a match made them more active in giving opinion. (4) question number 7 showed that $53 \%$ students said that through make a match they can work in a group when their teacher gave them some question.

\section{Reflection}

The data description above was used by the researcher to do reflection on teaching learning process in the next cycle. The result of test showed that the students' score is under the criteria of success. There are $41,38 \%$ students had reached criteria of success and $58,62 \%$ students did not reach criteria of success. It means that this result had not reached yet the criteria of success, because the criteria of success is $75 \%$ students had to get score above criteria of success but in the first cycle showed that only $41,38 \%$ students got score above criteria of success, so the researcher needed to apply Make a match in the next cycle to reach the criteria of 
success. Eventough students' achievement did not reach criteria of success but students' participation had reached the criteria of success because the questionnaire showed that more than $50 \%$ of students had reached the criteria of success.

\section{Revision}

Based on the reflection in cycle 1 , the researcher had to do next cycle in order to reach the criteria of success by doing some reviews, in order to the implementation in the next cycle or cycle 2 runs more effectively. The researcher revised some aspects that to be revised such as:

a. The researcher revised the lesson plan by making new lesson plan in different example of procedure text and developing strategy. The researcher added the materials in make a match strategy.

b. The researcher managed the time exactly because in the first cycle the time was not effective.

c. In doing make a match the researcher add some lessons. In the first cycle the researcher only gave a material in Make a match that is uncomplete, it means that the researcher give the steps of procedure text, but the steps is uncomplete yet, and the other card is the answer of uncomplete steps of procedure text.

d. The researcher gave present tense material in aplying Make a match, and give more vocabularies.

e. The researcher asked the students to make a question after the explanation the material. It can make the students more active and the researcher can control the students' understanding about the materials.

f. The researcher had to give more attention to students in implementing the method to carry out the students follow up exactly.

4. Cycle 2

a. Students' achievement

Students' achievement was gained from test in the form of essay. From the test in the second cycle that was given to the students there were 29 or all students reached criteria of success. It means that this research has done in the second cycle, because $100 \%$ of students had reached the criteria of success.

b. Students' participation
Questionnaire was given after implementing Make a match strategy were different with questionnaire in preliminary study. The result of questionnaire that related with students participation are: (1) question number 3 showed that $69 \%$ of students were motivated to study English when they solve the problem in a group. (2) question number 5 showed that $69 \%$ of students said that group presentation made students more active in asking question. (3) question number 6 showed that $59 \%$ of students said that group presentation made them more active in giving opinion. (4) question number 7 showed that $53 \%$ students said that they can work in a group when their teacher gave them some question.

\section{Reflection}

Based on the data which the researcher got in cycle 2, the researcher can conclude that the implementation of Make a match strategy could improve students' achievement in writing procedure. In the second cycle, the implementation of Make a match strategy is better than the first cycle, it showed that in the second cycle all students got score above 70 or $100 \%$ students got score above criteria of success, it means that the researcher did not need to continue to the next cycle.

\section{Discussion}

Based on the problem in preliminary study, the researcher used Make a match to solve the problem. The researcher gave explanation about the material before implementing the strategy. After the researcher explained the material about procedure text, the researcher explained about the rules how to do make a match strategy. The implementation of Make a match is, the teacher prepares some cards, where there is a question card and answer card. Then the students are given a card, where each student got different card, there are some students got question cards and some students got answer cards. The students who got question card should find the students who got answer cards. Because the material is procedure text, so the researcher change the question card into incomplete steps of procedure text, and the other cards is the answer, positive and 
negative sentence in present tense, generic structure of procedure text, and vocabularies related with procedure text in English and Indonesia. Then the researcher collect the data were related to the criteria of success. The criteria of success were students' achievement and students' participation. The students' achievement was from test, and students' participation was from questionnaire and field note.

Question number 1 in the questionnaire showed the indicator of students' characteristics which revealed students' interest in learning English, question number 2 revealed students' understanding, question number 3 and 4 revealed student's motivation, question number 5 and 6 revealed students' participation, question number 7 revealed students' group work. Question number 8 showed the indicator of learning device. It was the media. And question number 9 and 10 showed the indicator of writing.

These are the result of questionnaire: (1) $69 \%$ of students were motivated to study English when they could solve the problem in a group, it related with the statement of Pratiwiningsih (2013) that make a match can increase students' motivation while in field note, the teacher said that the students were more active in learning English. (2) 69\% of students active in asking question it is in line with the statement of Pratiwiningsih (2013) that make a match can increase students' motivation while in field note the teacher said that not more that $50 \%$ of students were brave to ask some questions. It means that make a match strategy could make students active but not all students were brave to deliver the question. (3) $59 \%$ of students active in giving opinion, it supports the statement of Pratiwiningsih (2013) that make a match most of students could make opinion but only some of students were brave to deliver the opinion. It means that make a match make students active in making opinion but not all of students can brave to deliver the opinion. (4) 53\% of students could work in a group when the researcher asked some questions.

These are the result of questionnaire in cycle 2: (1) $69 \%$ of students were motivated to study English when they could solve the problem in a group, it related with the statement of Chotimah (2013) that make a match can increase students' motivation while in field note, the teacher said that the students were more active in learning English. (2) $69 \%$ of students active in asking question it related with the statement of Pratiwiningsih (2013)that make a match can increase students motivation while in field note the teacher said that not more that $50 \%$ of students were brave to ask some questions. It means that make a match strategy could make students active but not all students were brave to deliver the question. (3) $59 \%$ of students active in giving opinion, it related with the statement of Chotimah (2013) that make a match can increase students' motivation while in field note the teacher said that most of students could make opinion but only some of students were brave to deliver the opinion. It means that make a match make students active in making opinion but not all of students can brave to deliver the opinion. (4) $53 \%$ of students could work in a group when the researcher asked some questions, it supports the statement of Sitepu (2014) that is make a match can increase learning activity for their cognitive and physic while in field note the teacher said that most of students in a group could answer the question from the researcher.

\section{CONCLUSION}

To conclude, after conducting Classroom Action Research in teaching writing procedure by using make a match in VII F class of SMPN 1 Megaluh, make a match strategy can improve students' writing procedure. It was proven by the analysis in the previous chapter. The students can write a procedure text with the correct grammar, and suitable vocabularies. The result of research showed that students' achievement in writing procedure increased in cycle 1 and cycle 2 . In the first cycle $41 \%$ students had reached criteria of success, and $58,62 \%$ students had not reached criteria of success. The second cycle $100 \%$ students got score above criteria of success, where the highest score was 95 and the lowest score was 75 . Almost of students in the class agreed that Make a match should be applied in the 
teaching learning process. It was shown on questionnaire after applying the strategy.

\section{REFERENCES}

Ary, D., et al. (2006). Introduction to research in Education. USA: Wadsworth Group.

Brown, D., H. (2004). Language Assessment. San Fransisco Pearson Education Inc.

Chotimah, C. I. (2013). The Effectiveness of Using Make a Match Technique in Teaching Reading at Madrasah Muallimin Muallimat 6 Tahun Tambakberas Jombang. (Post Graduate), Universitas Islam Malang, Malang.

Curran, L. (1994). Metode Pembelajaran Make a Match. Jakarta: Pustaka Belajar.

Fachrurrazy. (2012). Teaching English as Foreign Language for Teachers in Indonesia. Malang: State University of Malang.

Harmer, J. (2008). The practice of English Language Teaching. England: Pearson Longman.

Ibrahim, M. (2000). Pembelajaran Kooperatif. Surabaya: Universitas Negeri Surabaya.

Johnson, D. W. \& Johnson, R. T. (1994). Learning together and alone, Cooperative, Competitive, and individualistic learning (4th ed ed.). Boston: Allyn and Bacon.

Koshy, V. (2005). Practical Guide: Action Research For Improving Practice. Sage: Paul Chapman Publishing.

Latief, A., M. (2013). Research Methods on Language Learning An Introduction. Malang: State University of Malang.

Pratiwiningsih, A. (2013). Make a Match Technique in Teaching Reading Comprehension Report Text. Skripsi. STKIP PGRI Jombang. Jombang.

Sitepu, A. S. R. \& Masitowarni. (2014). Improving Students' Achievement in Writing Procedure Text by Apllying Index Card Match Strategy. . Lau Baleng.

Zaini, H. (2008). Srategi pembelajaran aktif. Yogyakarta: Insan Mandiri. 